\title{
ПЕРЕКЛАДОЗНАВСТВО
}

УДК 811.111'27:811.161.2’27

DOI DOI https://doi.org/10.32838/2663-6069/2019.2-2/02

Ahieieva V.O.

V. O. Sukhomlynsky National University of Mykolayiv

\section{CROSS-CULTURAL COMMUNICATION AND TRANSLATION}

The article is dedicated to the problem of cross-cultural communication and the process of translation within it. It states about peculiarities of cross-cultural communication, its main types and forms. It denotes the relationship between the language and the culture, describes the aspects of possible influence of cross-cultural communication on the process of translation. It describes the reasons of difficulties in communication because of culture differences. Special attention is paid to the strategies of translation within cross-cultural communication.

Key words: communication, cross-cultural communication, translation, message transmission, difficulties in translation.

Formulation of a research problem and its significance. The process of globalization in modern world influences and even changes not only politics and economics but also the nature and the matter of human communication. The dissemination of international contacts and the interest to foreign languages definitely increase our attention to cross-cultural communication as to the scientific and practical branch of science that goes through the dynamic development in the whole world. At the same time we still have a true need in defining the matter of cross-cultural communication, formulation of its basic principles and the aspects of research.

Communication is one of the main components of human life. In general sense talking about cross-cultural communication we talk not only about information exchange. We should also take into consideration all the other processes connected with it. Among these processes we may observe: ways of conveying and receiving information, the artificial intelligence laws, computer networks and programs, signs etc. Crosscultural communication in its general sense is the science that studies verbal and non-verbal communication among people belonging to different national and lingual cultural communities. Language proficiency is an internal part of cross-lingual communication and the key point in providing successful communication. When people don't know the language of an interlocutor they have to find translators (or interpreters) for providing this type of communication. So, summarizing all the above mentioned, we may easily say that translation (or interpreting) is an internal part of cross-cultural communication.

The goal and the specific tasks of the article. The main goal and the tasks of the article are dedicated to the problem of peculiarities of cross cultural communication and to the process of translation. The task of the article is to show the way cross-cultural communication may influence the process of translation and to show the problematic areas of translation in cross cultural communication.

Analysis of the latest research into this problem proved that the problem of cross-cultural communication was studied by many scholars. Most of their works were dedicated not only to the problem of this type of communication but to the aspect of it where cross-cultural communication, its peculiarities and significance are detected. Among the most famous scientists we may easily single out E. Haugen, V. Karaban, S. Semchinskiy, Yu. Zhluktenko, U. Wainreich and others. Their researches are devoted to studying the dialogue of cultures, the cultural code and the cultural context. It's a well-known fact that while translating we have to take into consideration cultural peculiarities that may influence the whole process of translation. It is proved that any translator faces difficulties in his/her work as his/her task is not only to convey the information but to convey it appropriately. In cross-cultural communication one of the main problems is that some languages are full of cultural 
terms and expressions (which are also called cultural specific). The cultural specific expressions are quite difficult to translate. This happens because the cultural context is too vague as it represents the world view and the world perception of a society [3].

Statement regarding the basic material of the research. Communication as a general phenomenon is the process of the message transmission consisting of three parts - the sender, the message and the recipient. In other words, it is the process of exchanging ideas, information etc. between two or more people. Communication has always been an important need of all societies and it is still an integral part of our life. It may occur between people of the same culture (and language) and of different cultures (and languages). The latter means the transmission of information through cross-cultural communication and the difficulties we face in it. It's not only cultural specific expressions (as it was mentioned above) but also facial expressions, gestures with universal and different meaning in different cultures etc.

But why do we talk about the relationship between the language and the culture, their connection and the difficulties in communication within them? First of all, it is because of the fact that while interacting with another language we also interact with another culture that speaks the language. The second point is that it's impossible to understand one's culture without accessing its language directly. Modern scholars often use the term "paralanguage" in cross-cultural communication to show the process of transmitting messages. Of course, this language phenomenon is specific to a culture. The subtype of paralanguage is kinesics, that is, the postures, expressions and gestures used as non-verbal language. It is proved that due to paralanguage we may change the meaning of various words by changing the tone of voice or the character of the voice.

Anthropologist-linguist Edward Sapir proved that the language habits of definite groups of people built the real world. After that he also stated that no two languages or similar in such a way that they would represent one society. The world for every society is different. This defines that speaking a language means that a person is assuming a culture. The knowledge of culture formulated on this principle means the knowledge of particular language [5].

By many scholars the process of translation in cross-cultural communication is often regarded as the cross-cultural communication agent. It always involves both language and culture simply because they two cannot be separated. Translators always have to pay attention to differences in kinds and degrees of conventionalization in the source and target cultures when conveying the message from one culture to another. One of the main peculiarities of translation in cross-cultural communication is its double-bind situation when a translator has to combine the source text in its cultural context to the target communicative and cultural condition. Dr. Datta Sawant in his latest research states that the cultural interaction can be studied through translation and that cultural connotations play an important role in translation studies.

But what are the main types of cross-cultural communication and how can they be influenced by translation? What difficulties may the translator face in cross-cultural communication and what problems may be observed according to these types?

Scholars define three types of cross-cultural communication. They are: verbal, non-verbal and visual ways of cross-cultural communication. Among them verbal type (which is also called language communication) is taken into consideration as an effective way to cross-cultural communication. In our everyday life representatives of different cultures do not analyze the elements of their cultural activities as we all live by stereotypes. These stereotypes help us to orient in different situations and we don't need to think how to act or how to react. In general meaning these stereotypes are positive because they are commonly accepted. But sometimes they have negative consequences as they may prevent us from estimating contradictions that may be present in social spheres of human life.

So, translation in cross-cultural communication mustn't be influenced by stereotypes of behavior as they are different in different cultures. As for the functions of translation in cross-cultural communication it is first of all the function of breaking misunderstanding among representatives of different cultures. Then it is the communicative function as a translation process is the transmission of information first of all. And the third function is the comparison and the correlation of language units.

And what are the main difficulties for translators in cross-cultural communication? First of all the translator has to choose what kind of translation he/ she has to do, whether it will be free or literal. Literal translation means word for word translation. And free translation means that the translator will not follow the form of the source language text closely. The traditional dichotomy between literal and free translation has been replaced by various up-to-date theories like Roman Jakobson's semiotic approach to translation where the translator has to recode the source language text (or message) first and after that he has to transfer it into an equivalent text (or message) for 
the target culture involving two equivalent messages in two different languages [4].

It is of vital importance to know the customs and the culture of people using the language the text is translated into. This may be announced only because any language is not just a nomenclature for a set of universal concepts, but the set of peculiar concepts (culture specific concepts). They are language units existing in the source language, but completely unknown in the target language. So, in the process of translation in cross-cultural communication we face the difficulty to find an appropriate equivalent.

To make an appropriate translation within crosscultural communication the translator has to define the need, the motivation and the purpose of translation. To do this he/she has to resort the knowledge of the target language culture and to restore his/her previous experience with similar texts that has been translated already. In general, if the translator works within cross-cultural communication, it is necessary to overcome the lack of equivalence, cultural untranslability and the losses in translation. To compensate all the above mentioned translators usually use generalization, the strategy of translation by a more specific term, that is, hyponym, the strategy of translation by cultural substitution, translation by paraphrase and the strategy of translation by omission [5].

One of the most commonly applied strategies of translation in cross-cultural communication is generalization which deals with different kinds of translation problems. The usage of generalization means that the translator uses a word or even the whole concept with a more general (superordinate) meaning instead of a more specific word or the concept. The result of this translation strategy may appear in excessive generalization and even in oversimplification, that is, the loss in meaning in the target language text.

The next strategy is the strategy of translation by a more specific term (or hyponym). This type of strategy is not so widely observed in translation within cross-cultural communication because of the fact that it is easier while we search for more general word. Another negative quality of this strategy is that it leads to over interpretation and oversimplification of the source language meaning.

One more type of translation strategy is the translation by cultural substitution which involves substitution of a culture specific item or expression. This type of strategy should be used carefully as we have to replace a culture specific item in the source language text by a target item with the similar concept in target culture to provide a similar impact on the target language reader. Like the previous strategy it also has both negative and positive qualities. The positive quality is that it allows the readers to identify a concept, and it becomes easily recognized. This method also permits to avoid the usage of long explanations or footnotes. The negative quality of this strategy is that it may lead to overgeneralization and even cause misunderstanding.

The method of usage of loan words is widely used in dealing with culture-specific items. This method is used when we have a deal with newly formed or newly introduced concepts. The loan word is often followed with footnotes or explanations. They permit the reader to understand target language text appropriately. The choice of loan words in translation within cross-cultural communication depends on the purpose and the type of the text. The method of loan words usage is applied in the case if the translator intends to preserve the standards prevailing in a given society.

The method of translation by paraphrase in crosscultural communication is used if the word (or a concept) is localized in the target language. At the same time there is a huge difference in the form or the frequency of usage in source language text for example. In this case we talk about paraphrase with the usage of related words. If a word (or a concept) isn't lexicalized in the target language text, then the translator has to paraphrase it with the usage of unrelated words. In this case we also talk about advantages and disadvantages. The main advantage is that this method allows achieving a high level of precision in specifying the meaning of a word (or a concept). The negative quality is that this method, as a rule, causes filling a one-item slot with the footnotes comprising several items. One more disadvantage is that it may lead to disproportion in length of the source and the target language texts.

The strategy of translation by omission in crosscultural communication is observed in the case of items possessing extreme difficulties in translation. This method may lead to little harm to omit a word or expression in translation. Some loss of meaning is also inevitable within this method. This type of translation strategy is used not only in cross-cultural communication, but also in the cases of translation of texts belonging to different genres. In spite of the fact that omission has some disadvantages, we may also talk about the advantages of this method usage. The main advantage is that we can produce a smooth, understandable and quite readable translation preserving the value of rendering a particular meaning accurately in a given context.

Conclusions. Cross-cultural communication is the exchange of information between representatives 
of different cultures. This type of communication consists of three parts - the sender, the message, and the recipient. The process of communication between representatives of different cultures faces some specific difficulties. Among them we may easily single out cultural specific, facial expressions, gestures with universal and different meaning based on the principle of social need, culture and history. The process of transmitting messages within cross-cultural communication is often called paralanguage. It is often combined with kinesics, that is, the postures, the expressions and the gestures used as non-verbal language. It is paralanguage that influences the process of cross-cultural communication as it may change the meaning of various words by changing the tone of voice for example.

There are three types of cross-cultural communication. They are: verbal, non-verbal and visual ways of cross-cultural communication. One of the main difficulty for translators in cross-cultural communication is that he/she has not only to know or to understand the culture of the target language representatives, but to overcome the stereotypes of behavior in his/her own culture. Other words, we talk about psychological difficulties in translation. According to the latest researches the process of cultural interaction can be fully studied and presented due to the translation. Within it cultural connotations play an important role in translation studies.

The process of translation in cross-cultural communication performs several functions. The first of them is breaking misunderstanding among representatives of different cultures. The second one is the communicative function, as a translation process is the exchange of information first. And the third function is the comparison and the correlation of language units.

Some peculiar difficulties are observed in translation in cross-cultural communication (except psychological ones). Among them we observe the lack of equivalence, cultural untranslability and the losses in translation. To overcome them translators use specific translation strategies. They are: generalization, the strategy of translation by a more specific term, the strategy of translation by cultural substitution, trans- lation by paraphrase and the strategy of translation by omission. Each of them has its own advantages and disadvantages. Before choosing the appropriate strategy of translation translator has to define the need, the motivation and the purpose of translation. The strategy of generalization presupposes the usage of a word or even the whole concept with a more general meaning instead of a more specific word or the concept. The strategy of translation by a more specific term presupposes the search of more general word. The strategy of translation by cultural substitution involves substitution of a culture specific item or expression when we replace a culture specific item in the source language text by a target item with the similar concept in target culture to provide a similar impact on the target language reader. The strategy of usage of loan words is used in dealing with culture-specific items when we have a deal with newly formed or newly introduced concepts followed with footnotes or explanations. The strategy of translation by paraphrase in cross-cultural communication is used if the word (or a concept) is localized in the target language. The strategy of translation by omission in cross-cultural communication is observed in the case of items possessing extreme difficulties in translation.

The translation plays an important role in crosscultural communication as it allows representatives of different cultures to carry out full exchange of information. In translation process it is necessary to pay attention to cultural aspects of formation and the use of language and also to consider stereotypes of behavior of the individual. The main objective of the translator in cross-cultural communication is, of course, to establish connection between speaking and to break a language barrier. The leading role of the translation is overcoming cultural distances between communicants which are aimed at providing mutual understanding between them. The translator in that case has to own cognitive base, that is the structured set of knowledge national and cultural communities, both the, and another. It is important, first of all, because they form specific national - cultural mentality which needs to be considered during the translation.

\section{References:}

1. Карабан В. І. та ін. Попередження інтерференції мови оригіналу в перекладі (вибрані граматичні та лексичні проблеми перекладу з української мови на англійську) / за ред. В. І. Карабана. Вінниця : Нова книга, 2003. 208 с.

2. Фінкель О. М. Забутий теоретик українського перекладознавства / за ред. Л. М. Черноватого, В. І. Карабана. Вінниця : Нова книга, 2007. 438 с.

3. Baker M. In other Words. London : Routledge, 1992. 128 p. 
4. Bartell M. Internationalization of universities: a university culture-based framework. London : Higher Education, 2003. $150 \mathrm{p}$.

5. Bell R. T. Translation and Translating. London : Longman, 1991. $248 \mathrm{p}$.

6. Brown H. Douglas. Principles of language learning and teaching. New York : Longman, 2000. 186 p.

7. Robinson-Stuart G., Honorine N. Second culture acquisition: Ethnography in the foreign language classroom. Modern Language Journal. 1996 Vol. 8. P. 430-432.

\section{МІЖКУЛЬТУРНА КОМУНІКАЦІЯ І ПЕРЕКЛАД}

У статті досліджено проблему міжкультурної комунікаџї та процесу перекладу в ї̈ межах. Досліджено особливості міжкультурної комунікації, їі головні види та форми. У статті досліджено зв'язок між мовою та культурою, описано аспекти можливого впливу на процес перекладу. Проаналізовано причини труднощів у спілкуванні через різнищю культур. Особливу увагу приділено стратегіям перекладу, широко поширеним у межах міжкультурної комунікації.

Ключові слова: спілкування, міжкультурна комунікація, переклад, передача інформації, труднощі під час перекладу.

\section{МЕЖКУЛЬТУРНАЯ КОММУНИКАЦИЯ И ПЕРЕВОД}

В статье рассмотрена проблема межкультурной коммуникации и проиесса перевода в рамках межкультурной коммуникации. Исследованы особенности межкультурной коммуникации, ее главные виды и формы. В статье рассмотрено связь между языком и культурой, описано аспекты возможного влияния на процесс перевода. Проанализированы причины трудностей в общении из-за разниць культур. Особое внимание уделено стратегиям перевода, иироко используемым в рамках межкультурной коммуникации.

Ключевые слова: общение, межкультурная коммуникация, перевод, передача информации, трудности при переводе. 